\title{
The 2008 Malaysian Elections: An End to Ethnic Politics?
}

\author{
Thomas B. Pepinsky
}

\begin{abstract}
Malaysia's twelfth general elections, held on March 8, 2008, dealt a stunning blow to the incumbent Barisan Nasional regime. For the first time since 1969, the coalition did not receive its customary two-thirds majority in the lower house of parliament. Moreover, the opposition was able to form governments in five out of eleven peninsular Malaysian states. This article uses electoral, economic, and demographic data to test a number of potential explanations for these outcomes. Evidence indicates that the regime's decreased majority is the consequence of non-Malay voters' rejecting the incumbent regime in favor of secular opposition parties.
\end{abstract}

KEYwORDS: Malaysia, elections, authoritarianism, democratization, ethnic politics

he Malaysian general elections of March 8, 2008, were a landmark event in the country's political history. For the first time since 1969, the ruling coalition failed to gain more than a two-thirds majority of seats in the lower house of the Malaysian parliament. In five of eleven state elections on the Malay peninsula, opposition parties denied the incumbent coalition even a simple majority. These results stunned international observers and many Malaysians alike. Foreign media deemed the results a "political earthquake" (Agence France-Presse, March 9, 2008; Wall Street Journal, March 9, 2008). Echoing the comments of Democratic Action Party chairman Lim Kit Siang, opposition politicians and bloggers have termed the results a "tsunami." While the Barisan Nasional (BN, National Front) has formed a government and its simple majority in the parliament allows it to pass legislation, for the first time in Malaysia's history it will not be able to change the Malaysian constitution at will. These results are heartening for the prospect of electoral democracy in Malaysia and a shock to its long-standing electoral authoritarian regime. ${ }^{1}$ Furthermore, as Malaysia has recently played a central 
role in the comparative study of dominant-party authoritarian regimes, the results have important implications for the study of authoritarianism and democratization in the post-Cold War world.

Malaysia's twelfth general elections will be the subject of popular debate and academic scrutiny for some time. The online columnist Lee Ban Chen writes that 'the 'political tsunami' was truly surprising, but like tsunamis in nature, there certainly were causes, although they were not felt before it happened" (Lee 2008). ${ }^{2}$

In this article I use electoral, economic, and demographic data to dissect the antecedents and implications of the election results. I first clarify how the regime lost its two-thirds majority, showing that the dramatic decrease in the BN's parliamentary majority does not appear to be the result of economic grievances, generational shifts, intraparty factionalism, or any whole-scale rejection of the BN. Rather, it is the result of non-Malays in peninsular Malaysia rejecting the $\mathrm{BN}$ and voting for secular opposition parties. The United Malays National Organisation (UMNO) still retains the support of most Malays, and the Islamist opposition still struggles to make significant inroads outside of its historical bases of support. I reach these conclusions by examining statistical analyses of electoral returns, success rates of incumbents and new challengers, and state-level economic indicators, and by estimating the fraction of each of Malaysia's ethnic groups to have voted for each major political party in peninsular Malaysia.

I then consider why the regime lost the support of non-Malays, arguing that the $\mathrm{BN}$ regime has fallen victim to its own strategy of regime maintenance under a comparatively moderate executive. Institutionalizing ethnic differences within the governing coalition, the regime has historically ruled by favoring ethnic Malays over non-Malays, in particular over the country's large ethnic Chinese and Indian minorities. To maintain a supermajority, though, the regime has always depended on its coalition partners' ability to win some number of seats. UMNO's primary opposition is the Pan-Malaysian Islamic Party (PAS), whose Islamist platform UMNO uses as a foil to attract the votes of peninsular non-Malays (who are almost uniformly non-Muslim) to the BN. Prior to the twelfth general elections, Malaysia's comparatively moderate prime minister Abdullah Ahmad Badawi did not pursue this strategy of pitting opposition parties against one another to nearly the same degree as had his predecessors. Consequently, non-Malays' grievances against the BN boiled over at the polls, as Chinese and Indian voters rejected the BN when confronted with secular opposition parties that toyed with ending preferences. 
This article has both practical and theoretical implications. By subjecting explanations for the regime's loss to close empirical scrutiny, I clarify the origins of the BN's decreased majority, dispel misconceptions about its nature and its causes, and outline its implications for Malaysian politics over the coming years. This "quantitative case study" approach moves beyond impressionistic accounts, few of which can distinguish among the many candidate explanations for the March 8 results. From a broader theoretical perspective, I argue that Malaysia's twelfth general elections yield new insights into the political liberalization of authoritarian regimes. Many prominent studies of authoritarianism have used Malaysia to illustrate the dynamics of authoritarian rule in the modern era (see, recently, Brownlee 2008; Case 2004, 2005; Greene 2007, 255-296; Slater 2003). Although I link the election results to ethnic factionalism that is rather unique to the Malaysian case, Malaysia's experience recalls the examples of other "non-crisis transitions" such as those in Chile and South Korea and underscores the importance of elite moderation in the liberalization of authoritarian regimes.

\section{The Context and the Results in Brief}

Malaysian voters on March 8, 2008, cast ballots in two races. Throughout the country, voters elected representatives to the lower house of the Malaysian parliament (Dewan Rakyat, DR). In the eleven states of peninsular Malaysia and the East Malaysian state of Sabah, voters elected representatives to their state assemblies (Dewan Undangan Negeri). Elections for the Sarawak state assembly were held in 2006, while the Federal Territories of Kuala Lumpur, Putrajaya, and Labuan do not have state assemblies. The vast majority of contests were headto-head races between one $\mathrm{BN}$ candidate and another nominated by one of the country's main opposition parties. Malaysia is a constitutional monarchy with a British-style parliamentary government, so parliamentary elections determine which party or coalition of parties will form the country's government.

The dominant party in the incumbent BN coalition is the UMNO, a strictly Malay party. UMNO's main junior partners on the peninsula are the Malaysian Chinese Association (MCA) and the Malaysian Indian Congress, along with the multiethnic Malaysian People's Movement (Gerakan) and the tiny People's Progressive Party (PPP). A number of small local parties are based in East Malaysia, although UMNO is active in Sabah, the only state where non-Malay indigenous Malaysians 
(bumiputras) may join the party. Challenging the Barisan Nasional in the 2008 election were three main opposition parties: PAS, the Democratic Action Party (DAP), and the People's Justice Party (PKR). These parties had joined a coalition known as the Alternative Front (Barisan Alternatif, BA) to contest the 1999 general elections. However, the BA failed to make the progress that many had hoped that it would and dissolved in 2001 when tensions arose between the Islamist PAS and the social democratic DAP due to the former's advocacy of Islamic law in Malaysia. Despite the BA's dissolution, the DAP, PKR, and PAS coordinated informally during the nomination process to ensure that only one opposition candidate challenged each UMNO incumbent.

In the run-up to the March 8 elections, few believed that there were any real chances for meaningful political change through the ballot box. Academic interest has recently turned to the failure of Malaysia's panethnic reform movement (see, e.g., Nair 2007). Authors speculating about the twelfth general elections in the year preceding it appeared more preoccupied with high-level personnel issues within UMNO and their implications for the party's future leadership. These issues include the controversial rise of Khairy Jamaluddin, son-in-law of Prime Minister Abdullah Ahmad Badawi; retired Prime Minister Mahathir Mohamad's continued influence on UMNO politics (Pepinsky 2007); and a tantalizing scandal involving Deputy Prime Minister Najib Abdul Razak, whose close adviser Abdul Razak Baginda was jailed on suspicion of having orchestrated the murder of his Mongolian mistress (Case 2008). The overwhelming success of the $B N$ regime in the 2004 general elections, where it won 90 percent of all seats, presaged a "correction" in 2008. Still, the potential for opposition success of the magnitude witnessed on March 8 seemed remote, with Malaysian politics-frequently marked by such scandals and leadership tussles-appearing to operate "as usual."

In retrospect, several developments in the fall of 2007 and early 2008 indicated growing dissatisfaction with the BN. These developments suggest several hypotheses that might explain how and why the BN lost its supermajority. The political scandals just mentioned are one obvious point of departure, as they undermine Abdullah's image as Malaysia's "Mr. Clean." Accordingly, one explanation for the March 8 outcomes is that corruption and scandals at the highest level of Malaysian politics drove voters to reject the $\mathrm{BN}$ regime.

Ethnic relations also made headlines prior to the March 8 elections. Indians - a relatively small and disenfranchised group-were incensed by the regime's heavy-handed response to a series of peaceful protests 
by the Hindu Rights Action Force (Hindraf). Hindraf advocates for Indian rights in Malaysia and opposes the destruction of Hindu temples, a practice that it claims is organized by radical Islamists with government backing (Pillay 2007). Several Hindraf leaders were arrested and charged with sedition in November 2007, and security forces disbanded a peaceful demonstration in Kuala Lumpur several days later, arresting dozens of protesters (Asia Times, November 27, 2007). After the sedition charges were dismissed by the courts, five Hindraf leaders were detained under Malaysia's Internal Security Act (ISA), which provides for indefinite detention without legal recourse. Shortly after Abdullah dissolved parliament in February 2008, Hindraf leaders began to urge ethnic Indians to vote against the BN (The Hindu, February 17, 2008).

Ethnic tensions extended beyond the complaints of Indian Malaysians. Since the promulgation of the New Economic Policy in 1971 (Faaland, Parkinson, and Saniman 2003), "race" has been a central consideration for every policy decision. Long a bone of contention between the BN regime (which, led by UMNO, strongly supports proMalay policies) and its opponents (which oppose them as discriminatory), the regime's pro-Malay stance became a central opposition issue in the wake of the 2005 UMNO party meeting, during which education minister and staunch UMNO loyalist Hishamuddin Hussein brandished a keris (a traditional Malay dagger). This use of violent imagery angered many and illustrated the opposition's campaign against the BN's policies (Noor 2008). Along with the Hindraf affair, it suggests that ethnic grievances may explain the March 8 results.

The Hindraf protests were not the only protests to have taken place in the closing months of 2007. Others included a march by the Malaysian Bar Council on September 24 in protest of an alleged judgefixing scandal (Agence France-Presse, September 25, 2007), and, on November 10, a mass rally by Bersih, which advocates for free and fair elections in Malaysia (The Star, November 11, 2007). Both represent elements of Malaysian civil society's organizing for political reform, and both were confronted by Malaysian security officials.

Finally, in the run-up to the election, there were indications of growing dissatisfaction with Malaysia's economy, in particular with rising inflation. In the first three months of 2008, Malaysia's consumer price index grew 2.6 percent as compared to the first three months of 2007 , and the BN regime's management of basic goods prices has always been central to its political appeal. While petroleum subsidies kept fuel price growth lower than inflation, year-on-year inflation rates for food and beverages totaled 3.9 percent in January, 4.5 percent in 
February, and 4.9 percent in March (figures calculated from Table 5.12 in the Monthly Statistical Bulletin for March 2008 [Bank Negara Malaysia 2008]). Given that the prices of many goods are fixed by law but not in practice, these figures probably underestimate the "true" inflation rates in Malaysia. These economic factors constitute another potential explanation for the March election outcomes.

With the benefit of hindsight, it is clear that these developments foreshadowed the BN's surprising finish in the March 8 elections. Still, while Abdullah and others were aware of the possibility for some electoral backlash against inflation, they did not appear overly concerned (Agence France-Presse, February 13, 2008). And the possibility that the aforementioned issues would cripple the BN seemed remote. Put simply, they are by no means new to Malaysia. The BN regime has long struggled with corruption and cronyism, so the scandals of recent years cannot themselves explain the March 2008 outcome. The regime withstood two economic crises (1985-1986) and 1997-1999) that were far more severe than today's comparatively mild economic slowdown. The most pessimistic recent estimate, by the Malaysian Institute for Economic Research, is that the gross domestic product (GDP) will grow by "only" 4.6 percent in 2008 (The Star, July 18, 2008)—by contrast, Malaysia's GDP shrank by around 7 percent in 1998 .

Perhaps more important is that the $\mathrm{BN}$ regime has the tools at its disposal to discourage its challengers. In previous instances of political turmoil, the regime resorted to economic favoritism, ethnic intimidation, political coercion, and low-level electoral fraud to protect its rule (see Crouch 1996; Hilley 2001; Hwang 2003; Milne and Mauzy 1999). The BN's predecessor, the Alliance, navigated still greater political turmoil (1969-1971) by suspending parliament altogether (see von Vorys 1975, 259-390). Under Mahathir, political institutions increasingly channeled the demands of a powerful executive (Slater 2003), and in the wake of the 1997-1999 crisis, the regime tightened its grip further (Case 2004).

General elections were called for March 8, 2008. The campaign period was thirteen days-rather long by recent Malaysian standards (Ong 2008b) - and the timing led to fierce complaints from de facto opposition leader Anwar Ibrahim and others. With Anwar banned from electoral politics until April 15, 2008, following a questionable conviction on charges of corruption, the choice of March 8 prevented him from standing for elected office. Such an interpretation of the election's timing is probably true, but the early date also may have reflected concerns within the BN that a global economic downturn might further undermine Malaysia's economic prospects. Given Anwar's complaints 
and despite his preelection bravado, the results probably surprised even him. In parliamentary elections, BN parties managed to hold on to just over 63 percent of all available seats. Yet as the results in Table 1 make clear, the BN's downturn was far from uniform, and parties' fortunes varied dramatically by state.

At the parliamentary level, BN parties failed dramatically in Kelantan, Kedah, Kuala Lumpur, Penang, and Selangor and had rather mixed results in Perak. In other states, the BN fared quite well. It is important to recognize that opposition party success is far from uniform. In ethnically heterogeneous states such Penang, Perak, and Selangor, the multiethnic PKR and largely Chinese DAP were victorious. The greatest victories of PAS were in the "Malay heartland" states of Kedah and Kelantan, where PAS has long had a base of support, although for the first time it was able to win several seats in Selangor, Perak, and the Federal Territory of Kuala Lumpur.

The implications of this regional variation are twofold. First, on the peninsula, it suggests that historical legacies play a large role in the ability of parties to attract voters. The strength of UMNO in Johor, its historical center, remains evident in the fact that opposition candidates were able to make few inroads there. By contrast, the historical weakness of UMNO in the northern Malay heartland remains evident in the continued success of PAS in Kelantan, where PAS has long been successful, and Kedah, where pockets of PAS support have persisted for some time. In short, there is no evidence of a uniform or wholesale rejection of the BN. It suggests that institutional histories matter among the Malay parties based on the peninsula for their ability to attract voters on polling day (see Funston 1980 for a discussion of these parties in historical context), although it does not indicate precisely how they matter (i.e., socialization, party infrastructure, etc.). By implication, results confirm what appears to be a trend of growing regionalization of politics in Malaysia (on this trend, see Weiss 2000; Welsh 2004).

Second, these results show the BN's strength in East Malaysia. Electoral support for the BN was rather overwhelming, despite the fact that the two East Malaysian states have long played second fiddle to the peninsula in Malaysian politics. Aside from UMNO in Sabah, and a very marginal MCA presence there as well, the BN in East Malaysia is supported by regionally based parties. This level of support for the regime has important implications for postelection politics in the twelfth Malaysian cabinet, as I discuss later.

Overall, state assembly elections roughly parallel parliamentary elections, with the BN component parties' retaining just under 61 percent 


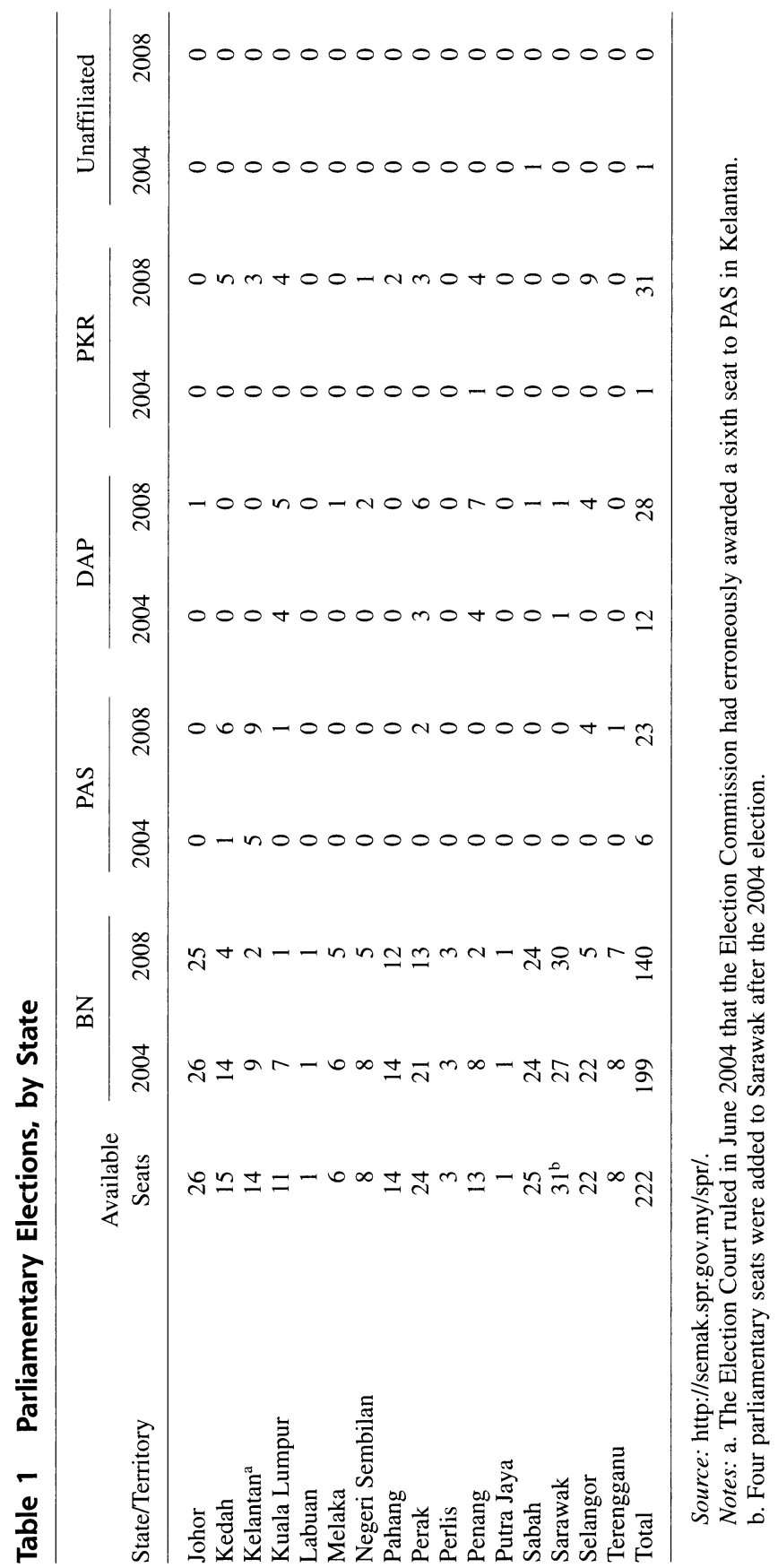


of all available seats. PAS did slightly better overall in state elections, capturing 16.4 percent of assembly seats against 10.4 percent of parliamentary seats; PKR fared slightly worse, capturing 7.9 percent of assembly seats against 14 percent of parliamentary seats; and the DAP did about the same. The fact that state election results roughly parallel parliamentary election results appears to be a new development. Previously, split-ticket voting was common, with many dissatisfied voters thought to be choosing the $\mathrm{BN}$ in local elections (where service provision is particularly salient) and voicing their opposition to the regime by voting for opposition candidates in parliamentary elections. Again, however, these totals obscure important variation around the country (Table 2).

One very important conclusion from the state assembly results in Table 2 is that with the exception of Kelantan-where PAS has long held a majority - no opposition party captured a simple majority of seats in a state assembly. Kedah, Perak, Penang, and Selangor must be led by coalition governments. Moreover, the types of coalitions that are sufficient to form a government vary by state. In Kedah, the natural coalition is between the dominant PAS and PKR-DAP has almost no support. By contrast, in Penang, the DAP is dominant and its natural coalition partner is PKR. Selangor and Perak are more evenly divided and require three-party coalitions to form any government (in Selangor, just barely). As I discuss later, this has important implications for opposition parties' political strategies, in particular the structure of their postelection coalition.

To foreshadow the discussion of comparative success rates across $\mathrm{BN}$ component parties on the peninsula, Table 3 shows the seats contested and won by BN parties there.

The success of UMNO roughly parallels that of the $\mathrm{BN}$ as a whole: decidedly popular in states like Johor, but unpopular in Kelantan, Kedah, and several others. While there were swings against UMNO in states like Selangor and Penang, the more notable losses were those by other BN component parties, which won very few of the seats that they contested in these multiethnic areas.

\section{Closer Analysis}

The surprising success of opposition parties in the March 8 elections calls for an explanation. A number of candidate explanations are amenable to quantitative testing, most drawing on the preelection developments already identified. One is the simple observation that the 


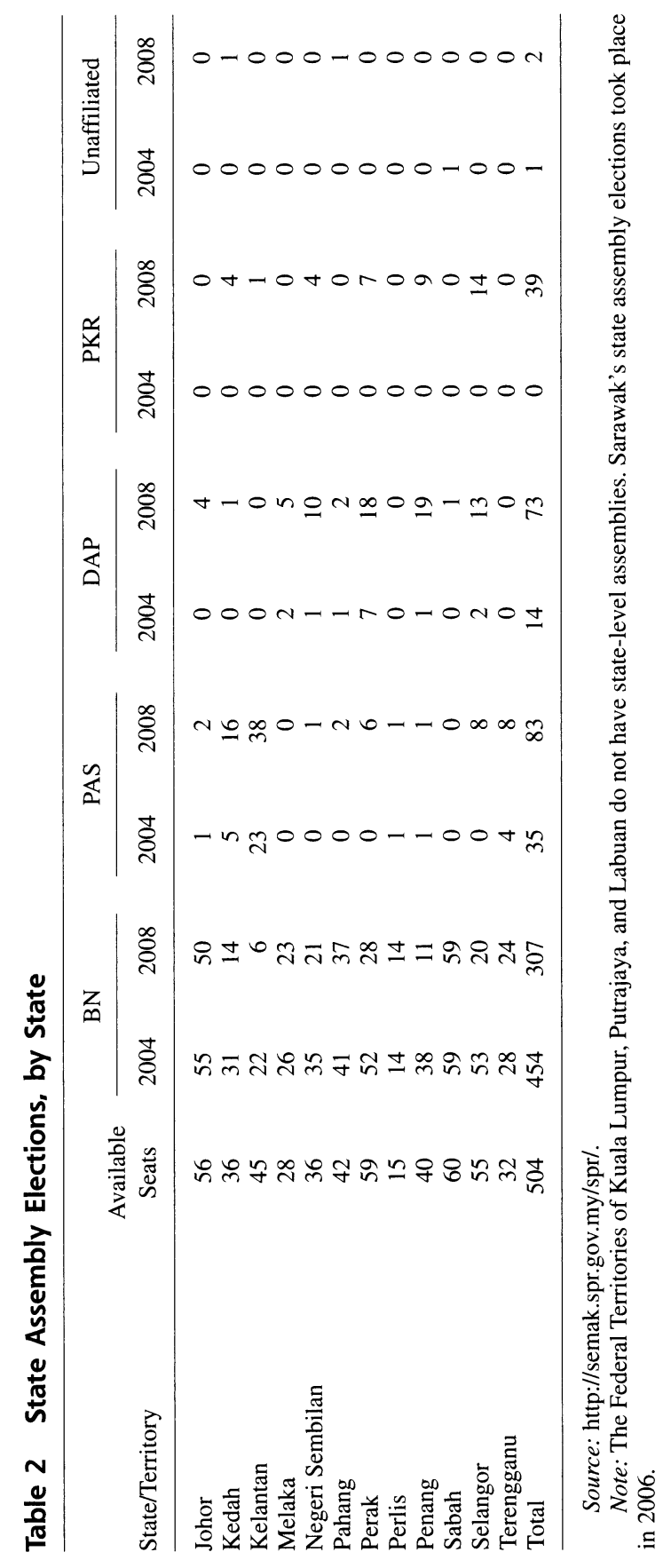




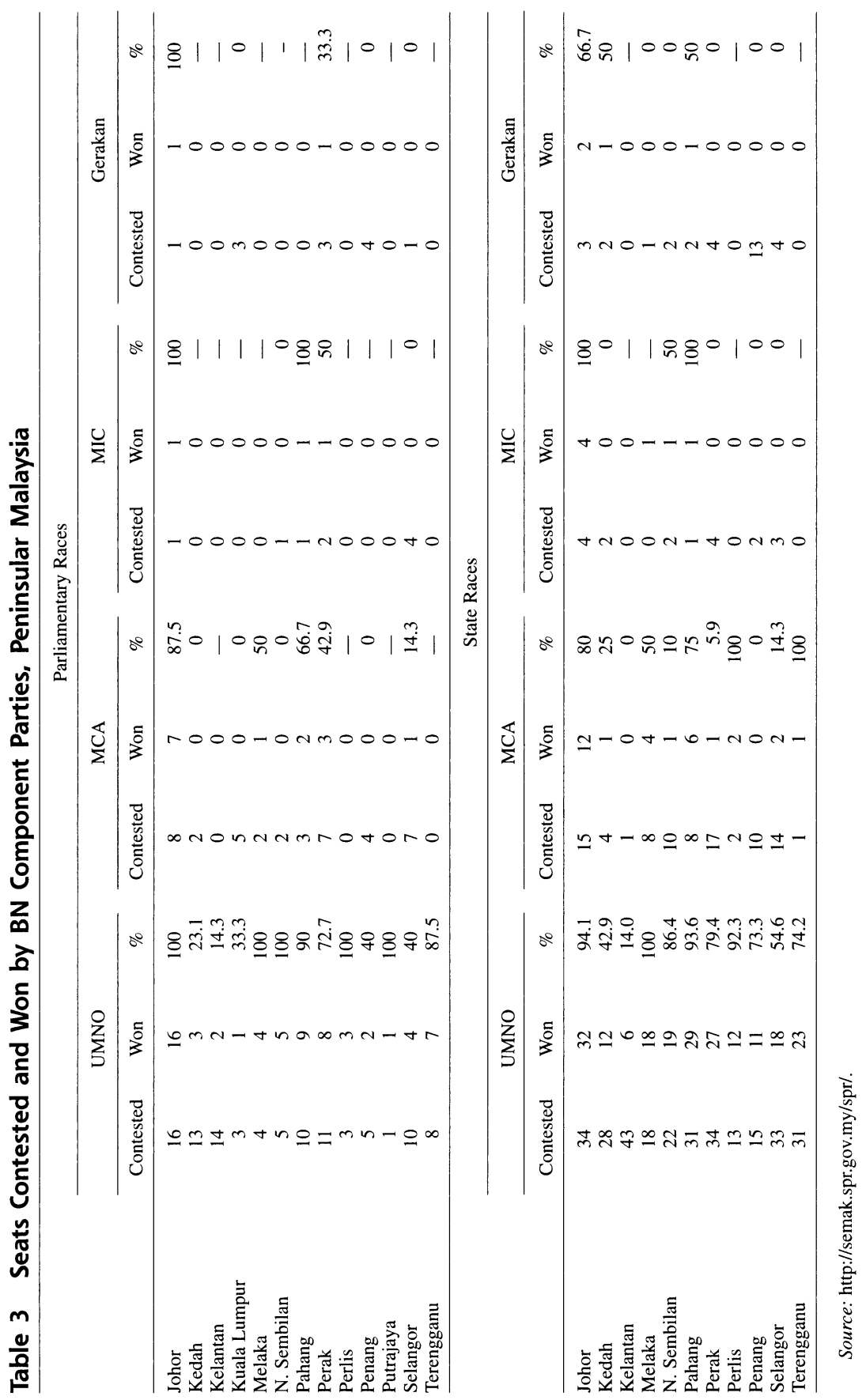


BN's losses occurred primarily among parties other than UMNO. Another is that economic grievances led voters to reject the BN. Still another attributes the BN's losses to the proliferation of new candidates in the 2008 elections, which may have undercut voters' identification with individual candidates. Looking at the areas where opposition parties were successful, some have argued that all opposition parties fared well against $\mathrm{BN}$ incumbents. Others argue that opposition victories were more frequent in districts with larger numbers of non-Malay voters and, more specifically, that non-Malay voters rejected $\mathrm{BN}$ parties at rates higher than Malay voters. These are the hypotheses that I test in the analyses below. In most of them, I focus on peninsular Malaysian states, for most of the claims made about the BN's failure to achieve a twothirds majority are implicitly ones about elections on the peninsula.

The first claim often made about the election results is that the nonMalay parties of the BN were the big losers in the March 8 elections. Table 4 confirms this.

Of the 103 parliamentary seats that UMNO contested on the Malay peninsula, it won sixty-five, almost two-thirds of them. By contrast, the other peninsular BN parties won less than one-third of the seats that they contested. In state elections, the difference between UMNO and other BN party success is even starker; UMNO won over two-thirds of the state seats that it contested, while other BN parties lost more than seven out of ten of the seats they contested. In both the parliamentary elections and state elections, Fisher's exact test shows that the difference between success rates of UMNO and other peninsular Malaysian parties is statistically significant at well beyond the 99.9 percent confidence level in one-tailed tests.

Table 4 Electoral Success in Peninsular Malaysia, UMNO Versus Other BN Parties

\begin{tabular}{|c|c|c|c|c|c|c|}
\hline & \multicolumn{3}{|c|}{ Parliamentary Elections } & \multicolumn{3}{|c|}{ All State Elections } \\
\hline & $\begin{array}{c}\text { UMNO } \\
\text { Contested }\end{array}$ & $\begin{array}{l}\text { Other BN } \\
\text { Contested }\end{array}$ & Total & $\begin{array}{c}\text { UMNO } \\
\text { Contested }\end{array}$ & $\begin{array}{l}\text { Other BN } \\
\text { Contested }\end{array}$ & Total \\
\hline \multirow[t]{2}{*}{ BN lost } & 38 & 43 & 81 & 95 & 101 & 196 \\
\hline & $36.89 \%$ & $69.35 \%$ & $48.48 \%$ & $31.46 \%$ & $71.13 \%$ & $44.14 \%$ \\
\hline \multirow[t]{2}{*}{$\mathrm{BN}$ won } & 65 & 19 & 84 & 207 & 41 & 248 \\
\hline & $63.11 \%$ & $30.65 \%$ & $51.52 \%$ & $68.54 \%$ & $28.87 \%$ & $55.86 \%$ \\
\hline \multirow{2}{*}{ Total } & 103 & 62 & 165 & 302 & 142 & 444 \\
\hline & $100 \%$ & $100 \%$ & $100 \%$ & $100 \%$ & $100 \%$ & $100 \%$ \\
\hline
\end{tabular}

Source: http://semak.spr.gov.my/spr/. 
Focusing on the seats that the BN lost rather than ones that it failed to regain, the results are even starker. This eliminates the confounding issue of seats that have long been held by opposition parties, in Kelantan especially but elsewhere as well. Did BN component parties fare differently when contesting as the incumbent? Table 5 answers this question by comparing the average rates of victory across $\mathrm{BN}$ parties in seats previously held by the BN.

The $\mathrm{t}$-statistics in Table 5 test the hypothesis that each BN component party fared worse than UMNO in the 2008 elections and take into account the fact that we have far more observations for UMNO contests than for others. The results demonstrate that each non-Malay BN party indeed fared significantly worse than UMNO in both parliamentary and state elections. Relative to one another, the March 2008 elections were a qualified success for UMNO and a disaster for other peninsular BN parties.

Several analyses of the 2008 election results have seized upon an economic explanation for the BN's relatively poor showing, linking the BN's failure to short-term economic hardship experienced by all Malaysians and to inequality across ethnic groups in particular. There are no data available to test whether short-term economic distress is associated with vote choice, but an alternative is to see if the BN fared worse in states experiencing higher levels of economic hardship. Such

Table 5 Comparing Seat Retention Rates in Peninsular Elections,
UMNO Versus Other BN Parties

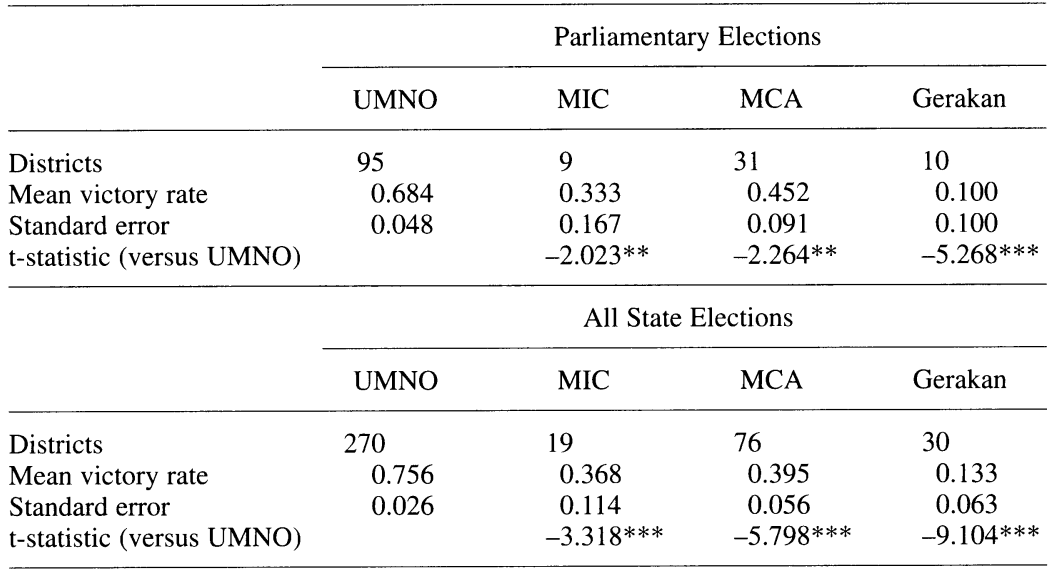

Source: Author's calculations.

${ }^{* * *} \mathrm{p}<0.01 ; * * \mathrm{p}<0.05$; one-tailed tests. 
contexts should heighten the impact of economic grievances on vote choice. Figure 1 presents four scatterplots of the percent of BN parliamentary victories using the most recent state-level development data available (Government of Malaysia 2006, ch. 17). ${ }^{3}$ Specific grievances included food and fuel prices, but data on fuel use and food price inflation by state is unavailable. Instead, I use indicators of development, poverty, growth, and urbanization rates to proxy for places where dissatisfaction with the $\mathrm{BN}$ might be highest. While these data come from 2004 and 2005, there is no reason to believe that the interstate patterns that they reflect are any different today than they were four years ago. These indicators, moreover, capture long-term trends in inequality and economic backwardness very well: states like Penang, Selangor, and Johor are the engines of Malaysia's growth, while states like Kelantan, Perlis, and Sabah are the country's poorest and most underdeveloped.

If economic hardship were driving the electoral results in Malaysia, we should find the BN faring worse in states that have long experienced more serious economic difficulties. If we find that the BN does well in both more and less developed states, then at the very least it suggests that economic hardship does not have a uniformly negative impact on BN support. These four plots show no clear relationship between state-level economic indicators and the success of BN parties. Only the 2004 poverty rate appears to have any relationship with BN vote shares, but it does so in the wrong direction-it appears that the states with higher poverty rates returned more $\mathrm{BN}$ candidates to office. I include Sabah and Sarawak in these scatterplots to locate them in relation to other states, but the lack of a relationship between economic conditions and BN success holds even when ignoring them. Similar patterns are apparent from state assembly elections. It is crucial to reiterate: these scatterplots cannot conclusively reject the hypothesis that the BN's relatively poor showing was a consequence of economic grievances held by individual voters, either those stemming from current economic conditions or long-term interethnic and interregional inequality. But they do suggest that such economic grievances have not uniformly driven voters from the $\mathrm{BN}$.

If not the economy, then what? One striking aspect of the 2008 elections is the new generation of BN politicians' contesting their first elections. Over 40 percent of all seats in the Dewan Rakyat, and about 37 percent of all seats in state assemblies, were not contested by incumbents. Only a very small minority of nonincumbent contests feature politicians switching constituencies or between parliamentary and state assembly contests. These numbers rise if we consider only $\mathrm{BN}$ incumbents and rise 


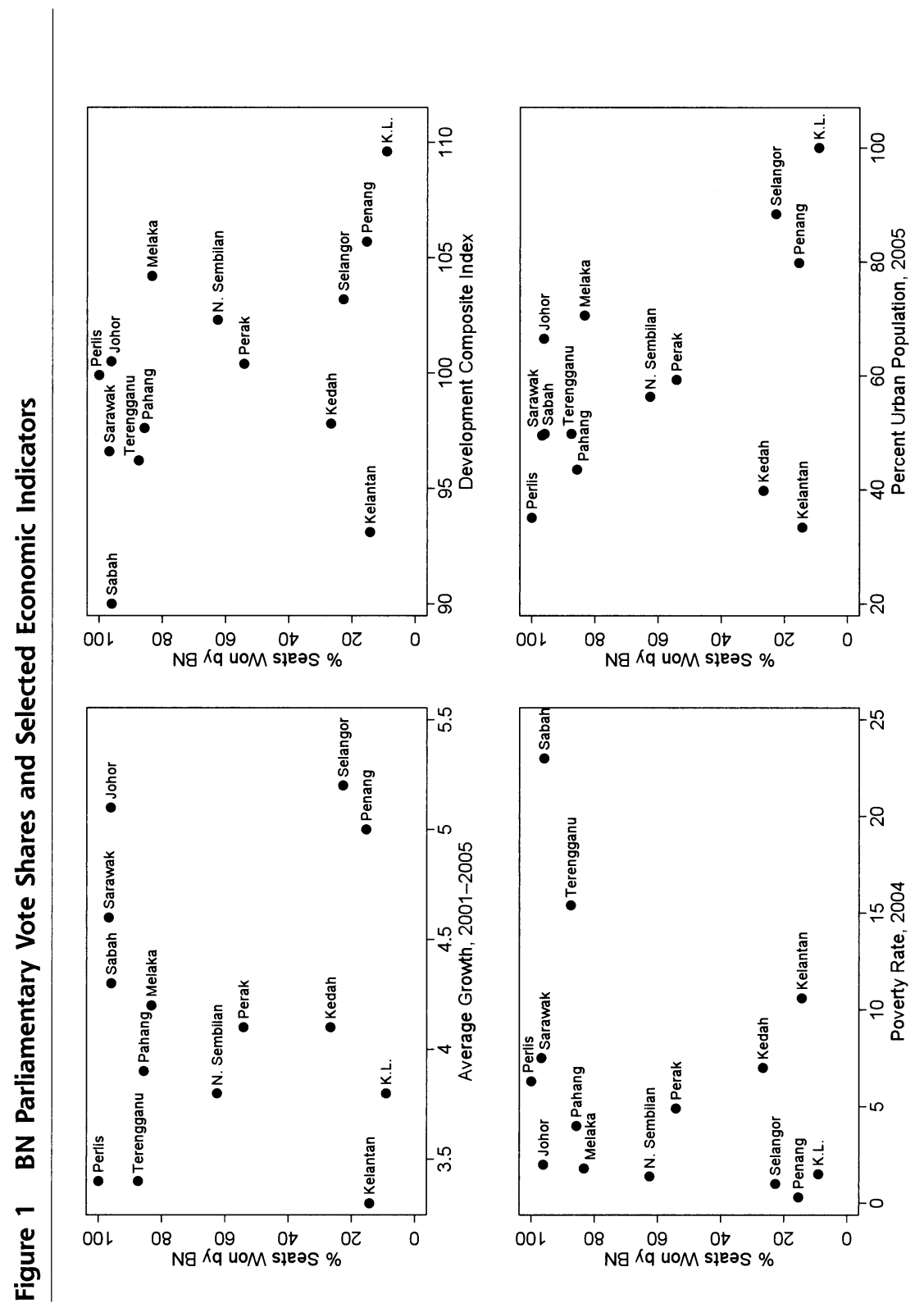


further if we exclude East Malaysia. The flood of newcomers is the result of a recent decision by Abdullah to delegate the task of candidate nomination to state-level $\mathrm{BN}$ party authorities. If party institutions in Malaysia are indeed weak as compared to the personal appeal of individual politicians, then the decentralization of the nomination process may have doomed the $\mathrm{BN}$.

If the BN's poor showing on the peninsula is the result of newcomers' dragging down the parties, we would expect to see that incumbents are more successful than newcomers. Table 6 and Table 7 investigate this question, breaking down elections in districts previously held by the $\mathrm{BN}$ by $\mathrm{BN}$ component party and incumbents versus newcomers.

Differential party and incumbency effects are quite apparent in these tables. In parliamentary elections (Table 6), incumbency was clearly no help to the Malaysian Indian Congress (MIC) or Gerakan. Likewise, the PPP (not shown) lost the only seat that it contested. MCA incumbents won 57 percent of seats, versus 35 percent for newcomers. Here the value of formal hypothesis testing is apparent, for this difference is not statistically significant at conventional levels. By contrast, the difference between victory rates for UMNO incumbents and newcomers is marginally statistically significant—at the 94.3 percent con-

Table 6 Electoral Success in Peninsular Malaysia by Party and Incumbency: Parliamentary Elections

\begin{tabular}{|c|c|c|c|c|c|c|c|}
\hline & \multicolumn{3}{|c|}{ UMNO } & & \multicolumn{3}{|c|}{$\mathrm{MCA}$} \\
\hline & Newcomer & Incumbent & Total & & Newcomer & Incumbent & Total \\
\hline \multirow[t]{2}{*}{$\mathrm{BN}$ lost } & 17 & 13 & 30 & $\mathrm{BN}$ lost & 11 & 6 & 17 \\
\hline & $41.46 \%$ & $24.07 \%$ & $31.58 \%$ & & $64.71 \%$ & $42.86 \%$ & $51.61 \%$ \\
\hline \multirow[t]{2}{*}{$\mathrm{BN}$ won } & 24 & 41 & 65 & BN won & 6 & 8 & 14 \\
\hline & $58.54 \%$ & $75.93 \%$ & $68.42 \%$ & & $35.29 \%$ & $57.14 \%$ & $48.39 \%$ \\
\hline \multirow[t]{2}{*}{ Total } & 41 & 54 & 95 & Total & 17 & 14 & 31 \\
\hline & $100 \%$ & $100 \%$ & $100 \%$ & & $100 \%$ & $100 \%$ & $100 \%$ \\
\hline \multicolumn{4}{|c|}{ 1-sided Fisher's exact $=0.057$} & \multicolumn{4}{|c|}{ 1-sided Fisher's exact $=0.197$} \\
\hline & \multicolumn{3}{|c|}{ Gerakan } & & \multicolumn{3}{|c|}{$\mathrm{MIC}$} \\
\hline & Newcomer & Incumbent & Total & & Newcomer & Incumbent & Total \\
\hline \multirow[t]{2}{*}{ BN lost } & 6 & 3 & 9 & BN lost & 1 & 5 & 6 \\
\hline & $85.71 \%$ & $100 \%$ & $90 \%$ & & $50 \%$ & $71.43 \%$ & $66.67 \%$ \\
\hline \multirow[t]{2}{*}{$\mathrm{BN}$ won } & 1 & 0 & 1 & $\mathrm{BN}$ won & 1 & 2 & 3 \\
\hline & $14.29 \%$ & $0 \%$ & $10 \%$ & & $50 \%$ & $28.57 \%$ & $33.33 \%$ \\
\hline \multirow[t]{2}{*}{ Total } & 7 & 3 & 10 & Total & 2 & 7 & 9 \\
\hline & $100 \%$ & $100 \%$ & $100 \%$ & & $100 \%$ & $100 \%$ & $100 \%$ \\
\hline \multicolumn{4}{|c|}{ 1-sided Fisher's exact $=0.700$} & \multicolumn{4}{|c|}{ 1-sided Fisher's exact $=0.583$} \\
\hline
\end{tabular}

Source: Author's calculations.

Note: Cells contain counts and percentages of column totals. 
Table 7 Electoral Success in Peninsular Malaysia by Party and Incumbency: State Assembly Elections

\begin{tabular}{|c|c|c|c|c|c|c|c|}
\hline & \multicolumn{3}{|c|}{ UMNO } & & \multicolumn{3}{|c|}{ MCA } \\
\hline & Newcomer & Incumbent & Total & & Newcomer & Incumbent & Total \\
\hline \multirow[t]{2}{*}{ BN lost } & 23 & 43 & 66 & BN lost & 20 & 26 & \\
\hline & $22.33 \%$ & $25.75 \%$ & $24.44 \%$ & & $58.82 \%$ & $61.9 \%$ & $60.53 \%$ \\
\hline \multirow[t]{2}{*}{$\mathrm{BN}$ won } & 80 & 124 & 204 & BN won & 14 & 16 & 30 \\
\hline & $77.67 \%$ & $74.25 \%$ & $75.56 \%$ & & $41.18 \%$ & $38.1 \%$ & $39.47 \%$ \\
\hline \multirow[t]{2}{*}{ Total } & 103 & 167 & 270 & Total & 34 & 42 & 76 \\
\hline & $100 \%$ & $100 \%$ & $100 \%$ & & $100 \%$ & $100 \%$ & $100 \%$ \\
\hline \multicolumn{4}{|c|}{1 -sided Fisher's exact $=0.314$} & \multicolumn{4}{|c|}{ 1-sided Fisher's exact $=0.484$} \\
\hline & \multicolumn{3}{|c|}{ Gerakan } & & \multicolumn{3}{|c|}{ MIC } \\
\hline & Newcomer & Incumbent & Total & & Newcomer & Incumbent & Total \\
\hline \multirow[t]{2}{*}{ BN lost } & 7 & 19 & 26 & BN lost & 9 & 3 & 12 \\
\hline & $100 \%$ & $82.61 \%$ & $86.67 \%$ & & $64.29 \%$ & $60 \%$ & $63.16 \%$ \\
\hline \multirow[t]{2}{*}{$\mathrm{BN}$ won } & 0 & 4 & 4 & BN won & 5 & 2 & 7 \\
\hline & $0 \%$ & $17.39 \%$ & $13.33 \%$ & & $35.71 \%$ & $40 \%$ & $36.84 \%$ \\
\hline \multirow[t]{2}{*}{ Total } & 7 & 23 & 30 & Total & 14 & 5 & 19 \\
\hline & $100 \%$ & $100 \%$ & $100 \%$ & & $100 \%$ & $100 \%$ & $100 \%$ \\
\hline \multicolumn{4}{|c|}{1 -sided Fisher's exact $=0.323$} & \multicolumn{4}{|c|}{ 1-sided Fisher's exact $=0.634$} \\
\hline
\end{tabular}

Source: Author's calculations.

fidence level in a one-tailed test. But note that even given this effect of incumbency, UMNO newcomers won well over half of the BN-held parliamentary seats that they contested.

In state assembly elections (Table 7), the irrelevance of incumbency and the failure of minority BN parties is again clear. MCA, MIC, and Gerakan newcomers and incumbents alike were unsuccessfulincumbency was no help for candidates in any of these parties. There is also no statistically significant difference between election rates for UMNO newcomers and UMNO incumbents, but this is because both groups were successful in about three out of four contests. Together, these results do not support an interpretation of the BN's poor showing in March 2008 being the result of a generational shift in BN candidates. Instead, the results suggest that voters evaluate BN parties based on their platforms rather than the appeal of individual candidates.

Another way to approach the March election results is to examine the fates of the opposition parties contesting. One common proposition about the March 8 elections is that all opposition parties performed well, as witnessed through the dramatic gains by PAS in Kedah, the DAP in Penang, and PKR in Selangor and Kuala Lumpur. If this were the case, then the identity of the opposition party contesting the election should 
not be correlated with the election outcome. Table 8 tests this proposition using probit regressions. The cells in Table 8 report the predicted change in the probability of a BN victory given the opposition party's running for a seat held by the BN. Positive numbers indicate a higher probability of the BN's winning, whereas negative numbers represent a higher probability of an opposition party's winning. The first three columns test the parties separately, and the fourth tests the relative effects of the PKR and DAP as compared to PAS. In the fifth and final column, I repeat the model in column 4 but include dummy variables (not reported) for each State or Federal Territory on the peninsula. This captures the fact that the general success of BN parties may reflect specific state-level variables (such as the historic strength of the BN in Johor).

These results demonstrate that across peninsular Malaysia, the opposition's greatest success was by PKR and DAP in seats previously held by the $\mathrm{BN}$, whereas PAS candidates by and large failed. Column 5 , for example, shows that even accounting for state-level differences, both the PKR and DAP candidates were more likely to defeat the BN than were PAS candidates.

The statistical models in columns $6-10$ are identical to those in columns $1-5$, but the data now come from all DUN (state assembly)

Table 8 Opposition Parties and BN Success

\begin{tabular}{|c|c|c|c|c|c|}
\hline $\begin{array}{l}\text { Parliamentary } \\
\text { Elections }\end{array}$ & Column 1 & Column 2 & Column 3 & Column 4 & Column 5 \\
\hline PKR contested & $\begin{array}{l}-0.303 \\
(0.211)\end{array}$ & - & - & $\begin{array}{l}-0.573 * * \\
(0.234)\end{array}$ & $\begin{array}{l}-0.719 * * \\
(0.313)\end{array}$ \\
\hline DAP contested & - & $\begin{array}{l}-0.589 * * \\
(0.285)\end{array}$ & - & $\begin{array}{l}-0.892 * * * \\
(0.312)\end{array}$ & $\begin{array}{l}-1.863 * * * \\
(0.487)\end{array}$ \\
\hline PAS contested & - & - & $\begin{array}{l}0.601 \text { *** } \\
(0.219)\end{array}$ & - & - \\
\hline No. of districts & 146 & 146 & 146 & 146 & 142 \\
\hline $\begin{array}{l}\text { All State } \\
\text { Elections }\end{array}$ & Column 6 & Column 7 & Column 8 & Column 9 & Column 10 \\
\hline PKR contested & $\begin{array}{c}0.198 \\
(0.141)\end{array}$ & - & - & $\begin{array}{c}-0.168 \\
(0.152)\end{array}$ & $\begin{array}{l}0.06 \\
(0.180)\end{array}$ \\
\hline DAP contested & - & $\begin{array}{c}-1.257 * * * \\
(0.172)\end{array}$ & - & $\begin{array}{l}-1.318^{* * *} \\
(0.181)\end{array}$ & $\begin{array}{l}-1.568 * * * \\
(0.229)\end{array}$ \\
\hline PAS contested & - & - & $\begin{array}{l}0.636^{* * *} \\
(0.131)\end{array}$ & - & - \\
\hline No. of districts & 395 & 395 & 395 & 395 & 395 \\
\hline
\end{tabular}

Source: Author's calculations.

$* * * \mathrm{p}<0.01 ; * * \mathrm{p}<0.05 ; * \mathrm{p}<0.1$; two-tailed tests.

Note: Standard errors in parentheses. 
elections on the peninsula rather than all DR (parliamentary) elections. They show one key difference between the successes of opposition parties in parliamentary versus state assembly elections. Columns 6,9 , and 10 show that running a PKR candidate against the BN appears to have no effect on the likelihood that the $\mathrm{BN}$ prevails. This is an interesting contrast with the parliamentary results, where PKR candidates were significantly more likely to defeat the BN than PAS. One possible explanation for this finding is that the DAP, with its long history and extensive local party machinery, is able to mobilize voters in local elections to a degree that the relatively new and nationally focused PKR cannot. Another is that the DAP allowed PKR to run in state-level seats that the opposition had no chance of winning. Substantively identical results were found in additional regressions that control for voter turnout and incumbency. These are not reported to save space.

We may also examine the proposition that the BN's loss is attributable to non-Malays' voting against the incumbent regime-versus the broader claim that all Malaysians rejected the regime. The former interpretation is far more common, but the latter interpretation has received limited attention among longtime observers of Malaysian politics (see Welsh 2008b). We can start by examining the data that do exist - the ethnic composition and vote returns of each parliamentary district - to see if districts with more Malays (or Chinese or Indians) were more or less likely to elect a BN politician. Data on district-level ethnic composition come from Utusan Malaysia (Utusan Online 2008). Table 9 shows the results of new probit regressions, in this case the marginal change in the probability of a $\mathrm{BN}$ victory by the ethnic makeup of the electoral district.

The methods here parallel those of Table 8: columns 4 and 9 show the relative impact of an increase in Chinese and Indian populations per district as compared to Malays, and columns 5 and 10 add dummy variables for each state on the peninsula.

The results indicate that in both state assembly and parliamentary elections, as the percentage of Malays in an electoral district increases, the likelihood of a $\mathrm{BN}$ victory increases. By contrast, as the percentage of Indians and Chinese increases, the likelihood of a BN victory decreases substantially. In column 5, for example, an increase of 1 percent in the ethnic Chinese population of a parliamentary constituency corresponds with a 5 percent decrease in the probability of a BN victory. With the exception of column 9, all of these results are highly statistically significant - and column 10 shows that the lack of significance for column 9 is likely due to a failure to account for state-level influ- 
Table 9 District Ethnic Populations and BN Success

\begin{tabular}{|c|c|c|c|c|c|}
\hline $\begin{array}{l}\text { Parliamentary } \\
\text { Elections }\end{array}$ & Column 1 & Column 2 & Column 3 & Column 4 & Column 5 \\
\hline Percentage Malay & $\begin{array}{l}0.016^{* * * *} \\
(0.004)\end{array}$ & - & - & - & - \\
\hline Percentage Chinese & - & $\begin{array}{c}-0.016 * * * \\
(0.005)\end{array}$ & - & $\begin{array}{l}-0.011^{* *} \\
(0.005)\end{array}$ & $\begin{array}{l}-0.053 * * * \\
(0.012)\end{array}$ \\
\hline Percentage Indian & - & - & $\begin{array}{c}-0.053 * * * \\
(0.015)\end{array}$ & $\begin{array}{l}-0.039 * * \\
(0.017)\end{array}$ & $\begin{array}{c}-0.048^{*} \\
(0.028)\end{array}$ \\
\hline No. of districts & 165 & 165 & 165 & 165 & 161 \\
\hline $\begin{array}{l}\text { All State } \\
\text { Elections }\end{array}$ & Column 6 & Column 7 & Column 8 & Column 9 & Column 10 \\
\hline Percentage Malay & $\begin{array}{l}0.017 * * * \\
(0.002)\end{array}$ & - & - & - & - \\
\hline Percentage Chinese & - & $\begin{array}{l}-0.020 * * * \\
(0.003)\end{array}$ & - & $\begin{array}{l}-0.018 * * * \\
(0.003)\end{array}$ & $\begin{array}{l}-0.049 * * * \\
(0.006)\end{array}$ \\
\hline Percentage Indian & - & - & $\begin{array}{c}-0.035^{* * *} \\
(0.008)\end{array}$ & $\begin{array}{c}-0.013 \\
(0.009)\end{array}$ & $\begin{array}{l}-0.027^{* *} \\
(0.013)\end{array}$ \\
\hline No. of districts & 443 & 443 & 443 & 443 & 443 \\
\hline
\end{tabular}

Source: Author's calculations.

$* * * \mathrm{p}<0.01 ; * * \mathrm{p}<0.05 ; * \mathrm{p}<0.1$.

Notes: Percentages defined as a proportion of all identified as Malay, Chinese, or Indian. Standard errors in parentheses.

ences on BN success. The picture that these results paint is one of the BN's enjoying more success among highly Malay districts, and the opposite in highly non-Malay districts. Given that the vast majority of PAS victories were in the heavily Malay districts of Kedah and Kelantan, Malays must have voted overwhelmingly for the BN outside of these states to have produced these findings. Again, substantively identical results were found in additional regressions (not reported) that control for voter turnout and incumbency.

While these results are suggestive, they do not allow us to ascertain whether or not individual Malay (or Chinese or Indian) voters fled BN parties. This is known among statisticians as the "ecological fallacy." For every district, we know only the distribution of ethnic groups and the distribution of support for the BN versus the opposition. The former is simply the percentage of the district that is ethnic Malay, Chinese, and Indian, and the latter is the percentage of votes that went to the $\mathrm{BN}$ versus an opposition party. But even if we know that a hypothetical district with 100 voters is 80 percent Malay and returns an 80 percent vote for UMNO, and we know that all voters voted, we cannot know if this is because all Malays voted for UMNO and no non-Malays 
did, or because non-Malays (twenty voters) voting for UMNO and only 75 percent of Malays $(.75 \times 80$ percent $=60$ voters $)$ did. This is a particularly serious challenge in Malaysia, where parties have clear ethnic bases but coalitions field only one candidate regardless of the extent of a district's ethnic heterogeneity. In statistical terms, the ecological inference problem prevents us from making individual-level claims about the joint distribution of ethnic identification and BN support from statelevel marginal distributions of ethnic identification and $\mathrm{BN}$ support.

Fortunately, a statistical technique known as EI (for "ecological inference") allows us to estimate average individual-level support for the BN by ethnic group using the aggregate data available (King 1997). The procedure is statistically complex, so I provide only the intuitions here. ${ }^{4}$ In the hypothetical district in the preceding paragraph, and again assuming uniform turnout, we know with complete certainty that the percentage of Malays who voted for UMNO is no smaller than 75 percent (and no larger than 100 percent). This narrows considerably the bounds on the possible percentage of Malays who voted for UMNO in that district. At the same time, all we know about the percentage of nonMalays that voted for UMNO in that district is that it is no smaller than 0 percent and no larger than 100 percent. But if we repeat this procedure for multiple districts, each of which has a different ethnic composition and a different result, we can combine the resulting information to estimate the average level of BN support among Malays and nonMalays across all districts.

This is the strategy that I adopt here. A generalization of EI to handle more than two ethnic groups (see Rosen et al. 2001) yields both an estimate of support for BN parties by ethnic group and a measure of the uncertainty associated with that estimate. Table 10 presents a list of estimates broken down by party contesting and allows differential turnout rates in each district to affect the estimates.

UMNO was able to garner over half of all Malay voters in the districts in which it ran-even when running against PAS. In MCA and MIC districts, an interesting contrast emerges. In districts where MCA ran, Malays appear to have voted for them at a substantially higher rate than they did for MIC candidates in districts where it ran. This suggests a lingering hostility to the DAP among Malays, one reflected in the fact that over 96 percent of Malays are estimated to have voted for the BN in districts where the DAP fielded a candidate! It is certainly true that in several urban constituencies, some Malays must have voted for opposition candidates in order for them to prevail (The Edge, March 13, 2008). But by and large, Malays remain the key constituency for BN 
Table 10 Ecological Inferences of Party Support in Peninsular Malaysia

\begin{tabular}{lccc}
\hline \multicolumn{3}{c}{ By BN Component Party Contesting } \\
\cline { 2 - 4 } & Malays & Chinese & Indians \\
\hline UMNO & 0.584 & 0.818 & 0.276 \\
& {$[0.575-0.594]$} & {$[0.799-0.837]$} & {$[0.257-0.295]$} \\
MCA & 0.519 & 0.328 & 0.412 \\
& {$[0.506-0.527]$} & {$[0.322-0.337]$} & {$[0.405-0.425]$} \\
MIC & 0.462 & 0.572 & 0.29 \\
& {$[0.404-0.516]$} & {$[0.541-0.6]$} & {$[0.253-0.325]$} \\
\hline & & By Opposition Party Contesting & \\
& & & Chinese \\
& Malays & 0.675 & 0.646 \\
& 0.61 & {$[0.666-0.682]$} & {$[0.633-0.658]$} \\
PAS & $0.601-0.62]$ & 0.375 & 0.401 \\
& 0.964 & {$[0.364-0.393]$} & {$[0.389-0.419]$} \\
DAP & $0.95-0.971]$ & 0.291 & 0.27 \\
& 0.754 & {$[0.281-0.299]$} & {$[0.251-0.285]$} \\
PKR & {$[0.739-0.773]$} & & \\
& & & \\
\hline
\end{tabular}

Source: Author's calculations.

Notes: Cells contain the fraction of each ethnic group estimated to have voted for BN component parties. In the EI model, marginal distributions of ethnic groups defined for each as a proportion of all identified as Malay, Chinese, or Indian; 95 percent confidence intervals around the estimates are in brackets.

parties. Although PKR and PAS fared better than the DAP among Malays, the estimates in Table 10 indicate that they attracted well under half of Malay voters in districts where they ran.

The estimates also suggest fascinating behavior among non-Malays. Ethnic Chinese voted primarily for UMNO in the districts where UMNO ran. In 2008, PAS ran a campaign opposing pro-Malay chauvinism in national politics while deemphasizing its Islamist platform. Still, when UMNO ran against PAS, an estimated two-thirds of ethnic Chinese votes went to UMNO. This certainly reflects resistance to PAS's historically Islamist platform, one customarily portrayed as hostile to non-Muslim Malaysians. Ethnic Chinese appear to have broken for both PKR and the DAP in substantial numbers; only about a third of Chinese voters are estimated to have voted for the MCA. These results accordingly confirm that among opposition parties, PAS still has difficulty attracting Chinese votes, whereas the PKR and DAP do not.

Ethnic Indians also appear to have rejected PAS overwhelmingly. And, in districts where the MIC fielded candidates, only three in ten Indians are estimated to have voted for them. In general, these estimates speak to a wholesale rejection of the BN by ethnic Indians, one appar- 
ent regardless of the BN party running. Indians appear to be somewhat more comfortable with PKR candidates than with DAP candidates, reinforcing that the PKR platform attracts more of a multiethnic vote than the DAP's.

One important caveat from these ecological estimates is that they are very sensitive to modeling choices. Like all ecological estimates, they are best understood as suggestive results that must be interpreted in light of the available qualitative evidence, and nothing more. In the present application, ecological estimates gel with other findings. The $\mathrm{BN}$ lost seats in the twelfth general elections in more heavily nonMalay peninsular constituencies, when parties other than UMNO contested and where the DAP or PKR rather than PAS contested.

If rejection of the $\mathrm{BN}$ by non-Malay voters on the peninsula explains the BN's diminished majority, what explains non-Malays' rejection of the BN? The answer cannot be simple ethnic favoritism, as this has long been the strategy through which the regime gained support from Malays. Why now, after nearly four decades, has the very strategy of regime maintenance that has been so successful failed? Some observers have suggested that the Malaysian voter today is different from the Malaysian voter of yesteryear. For instance, Malaysian voters may be more "sophisticated" now than ever before (Ong and Welsh 2007). The regime's hands-off stance toward the Internet-which enables online journalists to report on the $\mathrm{BN}$ in ways not possible in traditional media (Gan 2002) - may have played a key role in opposition organizing. While these observations may be true, I suggest that what has changed is the willingness of the current elites to employ the tactics that have protected it at election time-specifically, those that shore up its support among the non-Malay community. I attribute this to the leadership style of Prime Minister Abdullah himself.

A historical perspective on the March 8 results illustrates this point. Abdullah is no doubt more of a moderate figure than two of his predecessors as prime minister, Mahathir (1981-2003) and Abdul Razak Hussein (1970-1976). Before assuming the office of prime minister, Abdullah was known for his clean record, and his even temperament made him a less polarizing figure than Mahathir. Abdul Razak and Mahathir, by contrast, were so polarizing in part because of their fierce guardianship of BN supremacy. Abdullah's moderation comes at a cost, though, of rendering him unwilling to use the tools at his disposal to ensure the BN's electoral dominance. As one prominent observer has noted (Welsh 2008a), Abdullah's leadership has been weak, and many voters perceive him to be an ineffectual executive. Abdul Razak and 
Mahathir went to great lengths to use the tools available to them to prevail at the ballot box-lambasting soft-liners and liberals as tools of the West, jailing the BN's opponents, deploying the BN's resources to turn out supporters and suppress the opposition vote, and using the Malaysian media to argue that a DAP or PKR victory would upset the country's delicate ethnic balance and might empower a radical Islamist opposition (see Crouch 1996; Hilley 2001; Hwang 2003; Milne and Mauzy 1999; Weiss 2000). In the past, these tactics have kept nonMalays on the peninsula from turning out against the $\mathrm{BN}$ in large enough numbers. The BN's 2008 campaign featured none of these until after the elections.

It is not possible to "test" this explanation for the BN's failure to retain its supermajority in the same manner that I have examined other hypotheses in this article. But it does explain both the nature of the BN's electoral setback and its timing in light of Malaysia's political history. As I note in the concluding section, this explanation also situates the March 8 results in the broader comparative perspective.

\section{The Consequences}

In the immediate aftermath of the elections, some Malaysians feared the government might use mass celebrations to intervene and reverse the election results (see, e.g., Ooi 2008). This has not come to pass. Instead, BN leaders accepted the election outcomes and currently face the challenges of ruling with a decreased parliamentary majority. These results will have important effects on Malaysian politics over the coming years, both on party politics within UMNO and the BN and on the party strategies of the newly empowered opposition. The BN's main fear as of October 2008 is that enough members of parliament (MPs) will defect to the opposition that the $\mathrm{BN}$ will lose power altogether.

Within UMNO, the results prompted new debates about the party's future, especially that of the party leadership. As is customary given their positions as prime minister and deputy prime minister, Abdullah is UMNO president and Najib is UMNO deputy president. A bewildering series of claims and counterclaims about the potential for leadership turnover appeared in the Malaysian media in the wake of the election. Mahathir has resigned from UMNO in protest of Abdullah's rule (Berita Harian, May 20, 2008). One rumor even suggests that Tengku Razaleigh Hamzah, who in 1987 mounted a serious challenge to then prime minister Mahathir Mohamad and lost, was prepared to challenge 
Abdullah. To quell succession rumors, Abdullah announced that he would turn over UMNO leadership to Najib in mid-2010 (New Straits Times, July 11, 2008). Yet signs remain that some UMNO members are unsatisfied with this late date.

The mechanics of ruling with a smaller majority also introduce new dynamics into BN politics. The support of BN component parties in East Malaysia is more critical than ever before for the $\mathrm{BN}$, as $\mathrm{BN}$ parties hold just 52 percent of parliamentary seats from the peninsula. BN MPs from Sabah and Sarawak will likely play a far larger role in Malaysian national politics than they previously have. This is evident in both the initial demands by East Malaysian MPs for greater cabinet representation (Berita Harian, March 15, 2008) and in the responses from the opposition. One sign of the BN's new attentiveness to East Malaysian MPs is the leadership of the twelfth Malaysian parliament: its speaker is Pandikar Amin Mulia (UMNO/Sabah), and the deputy speakers are Wan Junaidi Tuanku Jaafar (PBB/Sarawak) and Ronald Kiandee (UMNO/Sabah). But East Malaysians today hold only five cabinet positions, and none of them is in the "power" ministries of finance, internal security, education, and so on. UMNO's Anifah Aman, a Sabah MP who refused to serve in Abdullah's cabinet as a deputy minister, has stated that "the people of Sabah have had enough of being treated contemptuously like stepchildren" (New Straits Times, May 7, 2008). These statements show that the threat of defection is real. The government will likely continue to offer blandishments to BN MPs from East Malaysia in order to hold the coalition together. Likewise, the Pakatan Rakyat, the new opposition coalition, will likely continue to attempt to woo these MPs away from the BN.

On the peninsula, the BN struggles to maintain its former image of multiethnic solidarity. Without sustained effort to rebuild themselves, the non-Malay parties will no longer be viable "sidekicks" for UMNO, and the BN's ability to rule will suffer. In multiethnic Penang, where the PKR and DAP routed the MCA and Gerakan, Khoo Boo Teik sums up the challenge neatly (if coarsely): "Stop playing 'Kapitan China' and 'Kapitan Keling' (no insult intended) to UMNO's 'Tuan Melayu,' or be irrelevant" (Khoo 2008). ${ }^{5}$ The preceding analysis shows that MCA's weakness is not among Malay voters (who still prefer it overwhelmingly to the DAP) but among its own communal constituency. MCA president Ong Ka Ting has been surprisingly assertive since the election, advocating the rights of non-Muslims who have converted to Islam to then convert back, and emphasizing the MCA's rejection of Islamic law for non-Muslims (New Straits Times, May 1, 2008). These 
positions aim to show that MCA can advocate for Chinese rights from within the BN, their perceived failure to do so being a part of the DAP's recent success. Of course, such appeals to Chinese constituents have long been a staple of MCA's message. The BN's decreased majority means that MCA must find new ways to draw voters to it, and away from the DAP.

Far more difficult is the position in which Gerakan and MIC find themselves. To remain relevant at all, they must reconnect with their core constituencies. For the MIC, this means the Indian community that so clearly turned against the BN. But in some contrast to the MCA, the preceding analysis finds that the MIC has difficulties attracting all Malaysians, not just Indians. It is not clear what the future holds for the MIC. Longtime MIC president S. Samy Vellu lost his parliamentary seat in the elections to an avowed socialist, but as of October 2008, Samy remains MIC president. Like MCA president Ong, Samy has attempted to burnish his pro-Indian credentials, breaking publicly with UMNO by advocating the release of those Indian activists detained indefinitely in the highly charged Hindraf affair (Utusan Malaysia, April 2, 2008). But again, given its rather dismal performance among all ethnic groups on the peninsula, MIC must balance its attempts to reconnect to ethnic Indians with a broader message of competence that can appeal to all Malaysians.

Gerakan must reconnect to citizens (primarily non-Malays) of industrialized areas who espouse multiculturalism and more liberal democracy from within the ruling coalition. Recent testy interactions between Gerakan leaders and UMNO party stalwarts, though, have largely confirmed that the former's interests are subservient to the latter's (New Straits Times, March 19, 2008). It is increasingly clear that the DAP's social democratic message and PKR's multiculturalist message are far more credible to voters when articulated from outside the ruling coalition, and it is accordingly difficult to imagine Gerakan's next step forward. Its president and former chief minister of Penang, Koh Tsu Koon, lost his seat and offered to resign, but as of October 2008 he remains president.

Altogether, from the perspective of the $\mathrm{BN}$, the results of the March 8 elections are discouraging. The non-Malay BN parties must redouble their efforts to reach their core constituencies or face extinction. UMNO must accept the new importance that MPs from East Malaysia now have. UMNO's party institutions will face their toughest challenge yet in managing internal competition over leadership succession and the spoils of office. 
The opposition's prospects are naturally much brighter in the wake of the March 8 elections. Given that Kelantan remains the only state where a single opposition party can form a government, the newly victorious opposition parties have recognized the necessity of forming coalitions to rule the states in which they defeated the BN. This necessity raises the stakes for cooperation. Soon after the election, they pledged that regardless of individual state outcomes, they will all work together in every state that the BN does not control and subsequently formalized this agreement as the Pakatan Rakyat (PR, People's Pact), a formal opposition coalition (New Straits Times, April 2, 2008). Not satisfied with forming a unified opposition, some PR leaders believe that in the BN's weakened state, the time is ripe for the PR to lure defectors from the $\mathrm{BN}$, ending $\mathrm{BN}$ rule once and for all.

For the PR to last, however, it will require sustained effort from national party leaders to present a common platform for rule while policing the potential for squabbles between party stalwarts in each. The internal contradictions of the PR are probably more likely to matter at the state level than at the federal level. If the PAS-led coalition were to attempt to implement hudud (Islamic criminal law) in Kedah, for example, it is hard to imagine that this would have no consequences for the stability of the PR coalition government in Perak, where the DAP dominates and where the formation of an opposition government was particularly difficult (Berita Harian, March 15, 2008). As of October 2008, such issues have yet to present a serious challenge to the PR, but the long-term durability and compatibility of the PR remain unclear.

Issues of the PR's internal compatibility will likely remain on the horizon for the simple reason that BN politicians will keep them there. If the results of the ecological analysis are correct, most non-Malay voters on the peninsula are still highly suspicious of PAS and view UMNO as a far safer alternative. PR leaders recognize this and have begun the task of recasting PAS's image among non-Malays. Tian Chua, head of information for PKR, has likened PAS's role in the PR to UMNO's role in the BN, representing the interests of Malays as an ethnic group rather than Muslims as a religious group (New Straits Times, April 8, 2008). It remains to be seen if this rhetorical strategy will be (1) successful in comforting non-Malays who remain suspicious of PAS's motives or even (2) palatable to PAS's leadership and rank and file. Spinning PAS as a "party for Malays" also contradicts PAS's platform of antidiscrimination. Without its long-held goal of creating an Islamic state in its ideological arsenal, PAS has little to distinguish itself ideologically from UMNO. Likewise, Malay voters are still 
deeply suspicious of the DAP, which has long been critical of the national policy of Malay supremacy. It remains to be seen if the DAP will be able to make further political gains among the very ethnic group that for so long as benefited from this policy.

As Malaysian politics adjust to these new realities, as of October 2008 actual regime change has yet to occur. But it is possible that the opposition could lure enough defectors to enable the PR to form a federal government. Anwar Ibrahim will play a central role in any transition. Since April, Anwar has claimed that the opposition parties have already seduced a number of BN MPs into defecting to the PR, enough to allow the PR to form a government (Berita Harian, April 25, 2008; New Straits Times, September 16, 2008). In late June, though, Anwar came under investigation of having committed sodomy with a young male aide. He was arrested in July and released on bail, but he continues to faces charges, which Anwar and his legal team slam as "politically motivated." While Abdullah maintains that the Anwar case is beyond his control, few observers believe that the charges are anything other than an attempt to use the courts to shame Anwar and to divide the opposition. So far, such attempts have yet to bear fruit. Anwar's wife, PKR president Wan Azizah Wan Ismail, resigned her seat as MP for Permatang Pauh in July 2008. This enabled Anwar to contest her seat, which he won easily in an August 26 by-election. Immediately thereafter, he began to claim publicly that a mass of defections from the BN would allow the PR to form new government on September 16. This date has passed with no major upheavals, but these may still lie in the future.

One sign that true political liberalization has yet to occur is that the $\mathrm{BN}$ continues to wield the tools of authority. Much as before, the BN has formed a government, and substantial power still rests in the hands of the executive. In mid-September, the regime moved against two of its opponents, detaining them without trial under the ISA. ${ }^{6}$ One detainee, Raja Petra Kamarudin, runs a website called Malaysia Today in which he lambasts the BN and tracks the leadership's most embarrassing scandals. The other, Teresa Kok Suh Sim, is a DAP member of parliament known for her criticism of the BN. The regime alleges that each has insulted Islam-Raja Petra in several blog posts, and Kok in her alleged involvement in a petition asking a mosque to lower the volume of its loudspeakers-thereby threatening public order. Yet, while the ISA detentions probably hearten UMNO's "ultras," moderates in the party are displeased. Zaid Ibrahim, a liberal-minded UMNO cabinet minister, tendered his resignation over the affair (New Straits Times, September 15, 
2008). The regime's use of the ISA to intimidate the opposition demonstrates that the March 8 elections have not spelled the end of the BN's rule but reveal a divide among soft-liners and hard-liners in the party elite. The coming months will show whether the political tsunami will have swept away the old regime and brought true political liberalization.

\section{Conclusion}

Malaysia's regime is an exemplar of "electoral" or "competitive" authoritarianism, where elections are integral to the regime's stability but where they are neither free enough nor fair enough to be democratic. Other prominent examples of such regimes include Zimbabwe under Robert Mugabe and Mexico under the PRI. These regimes employ many strategies to ensure victory on polling day, and the fact that they so regularly succeed in their goals makes it all the more important to understand when they do not. The BN regime in Malaysia has held a twothirds majority in the DR since 1971, withstanding severe economic crises and polarizing leadership squabbles alike. Viewed against this historical record, the 2008 election results are a landmark event.

In this article, I have used quantitative analytical tools to analyze the factors underlying the 2008 election results. Despite losses in Kedah and Selangor, UMNO performed quite well in parliamentary elections when compared with the thrashing that other BN parties received. UMNO is strongest in its historical center of Johor and weakest in Kelantan and northern Malaysia, but this is consistent with historical trends. The BN also performed very well in East Malaysia. However, other peninsular BN component parties fared abysmally in parliamentary elections. As argued by Muhammad Muhammad Taib, UMNO information chief, "We [the BN] are only eight seats short of a two-thirds majority. We lost because of other contributory factors" (New Straits Times, April 3, 2008). That factor is large-scale abandonment of the BN by non-Malays.

While some Malays have certainly forsaken the BN, ethnicity remains critical for understanding Malaysian politics. PAS still has made few significant inroads anywhere outside of Kedah-while it gained a few seats in Perlis and Selangor and even gained one seat in Kuala Lumpur, its success is dwarfed by that of other opposition parties. While some will read PAS's new footholds outside of the Malay heartland as signals of its drawing some non-Malay support, among opposition parties, the elections were primarily a victory for PKR and DAP. 
In establishing this point, I have shown that neither economic conditions nor incumbency effects explain the aggregate distribution of support for the BN across Malaysian states and Kuala Lumpur. At the individual level, perceived economic hardship may explain vote choice, but BN candidates fared well in a number of wealthy and urbanized states (Johor, Melaka) as well as a number of poor and largely rural states (Terengganu, Sabah). On the peninsula, there is clear evidence that the greater the percentage of Malays in a district, the higher the likelihood of a BN victory in 2008. Likewise, the victory of the opposition on the peninsula appears to be the result of non-Malays' voting for the DAP and PKR; the BN was more likely to win when PAS opposed it than when the DAP or PKR did. Ecological analyses demonstrate that the traditional fault lines of ethnicity matter for vote choice: Malays still favor the MCA rather than the opponents that it faces (always the PKR or DAP), whereas Chinese still vote for UMNO rather than PAS, probably lending UMNO critical support against PAS in elections where the two faced off head-to-head.

This analysis confronts recent research on the dynamics of electoral authoritarian regimes - in particular, the mechanisms behind their liberalization and electoral defeat. Howard and Roessler (2006) emphasize that the presence of a preelection opposition coalition increases the likelihood that an authoritarian election results in political liberalization, but by any measure Malaysia's opposition was more united prior to the 1990 and 1999 general elections than it was in 2008. Two new theories of dominant party rule and collapse predict that regimes such as Malaysia's collapse when they can no longer deliver the goods to their supporters (Greene 2007) or at least when voters no longer believe that authorities can do so (Magaloni 2006). While it is not clear that Malaysia's authoritarian regime is bound to collapse, regional vote patterns and Malaysia's ability to withstand a far more serious economic challenge during the period 1997-1999 suggests that factors other than simple resource provision must be at play. Existing theories of party institutionalization and regime durability (Brownlee 2008; Geddes 1999) are very helpful in explaining how dominant parties rule but are mostly silent about the factors that eventually bring them down. Likewise, simple economic theories of authoritarian rule (Acemoglu and Robinson 2006) appear ill-suited to explain the contours of ethnicity, coalitional politics, and political change in regimes such as Malaysia's.

Against these perspectives, this analysis of Malaysia's March 2008 elections highlights the social bases of electoral support for authoritar- 
ian regimes and the role of elites in shaping authoritarian political tactics. A somewhat older literature on liberalization and transitions is useful for understanding these. Stephan Haggard and Robert Kaufman (1995, 75-108) emphasize both "long-term socioeconomic changes" and "domestic demands for political reform"- -each unique to the country in question-in explaining why regimes such as those in South Korea, Chile, and Turkey liberalized during relatively good times after having withstood severe economic crises. The intra-UMNO factionalism evident today in the wake of the March 2008 elections represents the very sorts of intraelite cleavages between soft-liners like Abdullah and hard-liners like Najib that have presaged liberalization in so many other authoritarian regimes (O'Donnell and Schmitter 1986). When soft-liners in power fail to pursue the strategies that have secured victory at the ballot box, elections become focal points for domestic opponents to shock the regime.

Whether or not Malaysia is in the process of long-term political liberalization, the March 8 elections are an unprecedented opportunity for the opposition. But UMNO elites, soft-liners and hard-liners alike, still have substantial political power, as Anwar, Raja Petra, and Teresa Kok will attest. For the 2008 Malaysian elections to yield true liberalization, the BN's soft-liners must come to believe that liberalization holds the key to their political survival, while hard-liners must be contained. Time will tell whether or not Malaysia's opposition can accomplish this.

Thomas B. Pepinsky is assistant professor of government and a member of the graduate field in Asian studies at Cornell University. He is author of Economic Crises and the Breakdown of Authoritarian Regimes (forthcoming, Cambridge University Press) and of articles appearing in World Politics, Studies in Comparative International Development, and other journals. His current research examines Islam, the economy, and voter preferences in democratic Indonesia.

\section{Notes}

This article benefited enormously from feedback from Bill Case, Ong Kian Ming, and Meredith Weiss. I thank them for the enthusiasm (and speed!) with which they provided comments on a very rough early draft. Thanks also to Stephan Haggard and the anonymous reviewers for their comments and suggestions. Boz Welborne provided outstanding research assistance. Replication files are available online at www.people.cornell.edu/pages/tp253/research.html. All errors are my own. 
1. The term soft authoritarian is just one of many terms used to describe Malaysia's regime. Others include competitive authoritarian, semidemocracy, and pseudodemocracy.

2. Lee's precise wording in Malay is "'tsunami politik' sungguhpun mengejutkan, ia juga umpama tsunami alam, pasti ada sebab musababnya meskipun ia gagal dikesani sebelum berlaku."

3. Data are not available for the Federal Territories of Labuan or Putrajaya.

4. A recent application to the study of voting returns is King et al. (2008). For another application of ecological inference to study Malaysian politics, see Ong (2008a).

5. The terms Kapitan China and Kapitan Keling stem from colonial Malaya and refer to Chinese and Indian figures who served as intermediaries between British rulers and their respective communities. In this context, these terms have rather negative connotations, implying that the Kapitan are something akin to lackeys. Tuan Melayu translates roughly as Lord Malay.

6. A third detainee, a reporter with a Chinese language daily, was released within a day.

\section{References}

Acemoglu, Daron, and James A. Robinson. 2006. Economic Origins of Dictatorship and Democracy. New York: Cambridge University Press.

Bank Negara Malaysia. 2008. Monthly Statistical Bulletin March 2008. Kuala Lumpur: Bank Negara Malaysia.

Brownlee, Jason. 2008. "Bound to Rule: Party Institutions and Regime Trajectories in Malaysia and the Philippines." Journal of East Asian Studies 8, 1: $89-118$.

Case, William. 2004. "New Uncertainties for an Old Pseudo-Democracy: The Case of Malaysia." Comparative Politics 31, 1: 83-104.

— 2005. "Southeast Asia's Hybrid Regimes: When Do Voters Change Them?" Journal of East Asian Studies 5, 2: 215-237.

- 2008. "Malaysia in 2007: High Corruption and Low Opposition." Asian Survey 48, 1: 47-54.

Crouch, Harold. 1996. Government and Society in Malaysia. Ithaca: Cornell University Press.

Faaland, Just, Jack Parkinson, and Rais Saniman. 2003. Growth and Ethnic Inequality: Malaysia's New Economic Policy, 2nd ed. Kuala Lumpur: Utusan Publications and Distributors Sdn Bhd.

Funston, N. J. 1980. Malay Politics in Malaysia: A Study of the United Malays National Organisation and Party Islam. Kuala Lumpur: Heinemann Educational Books (Asia).

Gan, Steven. 2002. "Virtual Democracy in Malaysia." Nieman Reports 56, 2: 65-67.

Geddes, Barbara. 1999. "What Do We Know About Democratization After Twenty Years?” Annual Review of Political Science 2: 115-144. 
Government of Malaysia. 2006. Ninth Malaysia Plan 2006-2010. Putrajaya: Economic Planning Unit, Prime Minister's Department.

Greene, Kenneth. 2007. Why Dominant Parties Lose: Mexico's Democratization in Comparative Perspective. New York: Cambridge University Press.

Haggard, Stephan, and Robert R. Kaufman. 1995. The Political Economy of Democratic Transitions. Princeton: Princeton University Press.

Hilley, John. 2001. Malaysia: Mahathirism, Hegemony and the New Opposition. London: Zed Books.

Howard, Marc Morjé, and Philip G. Roessler. 2006. "Liberalizing Electoral Outcomes in Competitive Authoritarian Regimes." American Journal of Political Science 50, 2: 365-381.

Hwang, In-Won. 2003. Personalized Politics: The Malaysian State Under Mahathir. Singapore: Institute of Southeast Asian Studies.

Khoo, Boo Teik. 2008. "The Monkeys Strike Back." Aliran Monthly 28, 2.

King, Gary. 1997. A Solution to the Ecological Inference Problem: Reconstructing Individual Behavior from Aggregate Data. Princeton: Princeton University Press.

King, Gary, Ori Rosen, Martin A. Tanner, and Alexander F. Wagner. 2008. “Ordinary Economic Voting Behavior in the Extraordinary Election of Adolf Hitler." Journal of Economic History 68, 4.

Lee, Ban Chen. 2008. "Sistem Dua Barisan Dalam Pembentukan?" www .malaysiakini.com/columns/79696 (accessed May 15, 2008).

Magaloni, Beatriz. 2006. Voting for Autocracy: Hegemonic Party Survival and Its Demise in Mexico. New York: Cambridge University Press.

Milne, R. S., and Diane K. Mauzy. 1999. Malaysian Politics Under Mahathir. London: Routledge.

Nair, Sheila. 2007. "The Limits of Protest and Prospects for Reform in Malaysia." Critical Asian Studies 39, 3: 339-368.

Noor, Farish A. 2008. "Now See What Happens When You Play Around with the Keris?" www.aliran.com/index.php?option=com_content\&view=article\& $\mathrm{id}=499$ :now-see-what-happens-when-you-play-around-with-thekeris\&catid $=55: 2008 \&$ Itemid=40 (accessed May 16, 2008).

O’Donnell, Guillermo, and Philippe C. Schmitter. 1986. Transitions from Authoritarian Rule: Tentative Conclusions About Uncertain Democracies. Baltimore: Johns Hopkins University Press.

Ong, Kian Ming. 2008a. "Making Sense of the Political Tsunami," www .malaysiakini.com/news/79604 (accessed May 15, 2008).

—. 2008b. "Who Gains Most from Longer Campaign Period?" www .malaysiakini.com/news/78483 (accessed May 15, 2008).

Ong, Kian Ming, and Bridget Welsh. 2007. "Malaysia After 50 Years: More Sophisticated Voters, More Sophisticated Politicians?" Paper presented at the 2007 annual meeting of the Association for Asian Studies, Boston.

Ooi, Jeff. 2008. “Tsunami," www.jeffooi.com/2008/03/its_a_tsunami.php (accessed May 4, 2008).

Pepinsky, Thomas B. 2007. "Malaysia: Turnover Without Change." Journal of Democracy 18, 1: 113-127. 
Pillay, Subramaniam. 2007. "Hindraf Rally: A Plea of the Dispossessed?" Aliran Monthly 27, 10.

Rosen, Ori, Wenxin Jiang, Gary King, and Martin A. Tanner. 2001. "Bayesian and Frequentist Inference for Ecological Inference: The R x C Case." Statistica Neerlandica 55, 2: 134-156.

Slater, Dan. 2003. "Iron Cage in an Iron Fist: Authoritarian Institutions and the Personalization of Power in Malaysia." Comparative Politics 36, 1: 81-101.

Utusan Online. 2008. "Pilihan Raya Umum Ke-12," www.utusan.com.my/ utusan/special.asp?pr=pilihanraya2008 (accessed May 15, 2008).

von Vorys, Karl. 1975. Democracy Without Consensus: Communalism and Political Stability in Malaysia. Princeton: Princeton University Press.

Weiss, Meredith L. 2000. "The 1999 Malaysian General Elections: Issues, Insults, and Irregularities." Asian Survey 40, 3: 413-435.

Welsh, Bridget. 2004. "Real Change? Elections in the Reformasi Era." In The State of Malaysia: Ethnicity, Equity and Reform, ed. Edmund Terence Gomez, 130-156. London: RoutledgeCurzon.

2008a. "Election Post-Mortem: Top 10 Factors," www.malaysiakini .com/news/79677 (accessed May 15, 2008).

. 2008b. "Malaysia's Democratic Opening," www.worldbulletin.net/ author_article_detail.php?id=1609 (accessed May 15, 2008). 